\title{
Synthesis of Self-colored Thermal Stabilized Acrylonitrile/Itaconic Copolymers
}

\author{
AZZA ABDULLAH AL-GHAMDI* \\ Chemistry Department, College of Science, Imam Abdulrahman Bin Faisal University, \\ P.O.Box1982, 31441, Dammam, Saudi Arabia. \\ *Corresponding author E-mail: azaalghamdi@iau.edu.sa \\ http://dx.doi.org/10.13005/ojc/350240
}

(Received: January 30, 2019; Accepted: March 28, 2019)

\begin{abstract}
Acrylonitrile (AN) was copolymerized with itaconic acid metal complexes [Co(II), Ni(II), $\mathrm{Cu}(\mathrm{II})]$ aiming to synthetize self-colored acrylonitrile fiber. The copolymerization occurred in water at $60^{\circ} \mathrm{C}$ using sodium bisulfite and potassium persulfate as redox initiators. The resulting copolymers are colored and exhibited high thermal stability as shown from their TGA curves. The investigated copolymers exhibited comparable thermal stability as that of PAN. The AN/ itaconic acid Co $\left(\mathrm{NO}_{3}\right)_{2}$ copolymer was considerably the most thermal stable copolymer while that of $\mathrm{Ni}(\mathrm{II})$ copolymer was the less stable one. $\mathrm{Cu}(\mathrm{II})$ copolymer showed an intermediate stability. The data also revealed that the maximum degradation occurred after $300^{\circ} \mathrm{C}$ (the cyclization temperature). Thus, neither the copolymerization nor the complexation affected the nitrile oligomerization reaction. The effect of adding ammonium hydroxide solution to acrylonitrile-itaconic acid copper(II) complex copolymer on the thermal stability of copolymer was also studied.
\end{abstract}

Keywords: Thermal analysis, Acrylonitrile copolymers, Self-colored poly acrylonitrile.

\section{INTRODUCTION}

Polyacrylonitrile (PAN) is known to suffer from several disadvantages: weak modability, thermal instability at high temperature as well as poor dyeability. Copolymerization has been proved to be an effective route for the modification of the polymer properties generally and of poly acrylonitrile (PAN) particularly. It is reported that the essential properties of PAN can be greatly improved by the incorporation of different comonomer units ${ }^{1-7}$ into the polymeric matrix. The thermal instability as well as the poor dyeability are the main properties to be improved.

Acidic comonomers such as itaconic acid (IA) offered additional sites which could, which could modify the fiber morphology, increase the hydrophilicity and facilitate the cyclization of the nitrile group during thermal oxidative stabilization of acrylic fibers ${ }^{8,9}$. It has been reported that itaconic acid does not homopolymerize easily since its radical possesses poor reactivity towards its own monomer unit ${ }^{9}$.

This is an Open Access article licensed under a Creative Commons license: Attribution 4.0 International (CC- BY). Published by Oriental Scientific Publishing Company @ 2018 
However, the presence of two carboxylic groups in itaconic acid monomer increases the possibility of interaction of the carboxylic group with the nitrile group during cyclization reaction 10 leading to cross-linked structure. A suggestion for the deactivation of the effect of carboxylic groups on the formation of the cross linked structure is the treatment of itaconic acid (IA) with some metal salts as $\mathrm{Ni}\left(\mathrm{NO}_{3}\right)_{2}, \mathrm{Cu}\left(\mathrm{NO}_{3}\right)_{2}$ and $\mathrm{Co}\left(\mathrm{NO}_{3}\right)_{2}$ before its copolymerization with acrylonitrile (AN). The metals gave the copolymer its natural color. There will be no need for the dyeing process as well as the problem of fasting of the dye on the polymeric matrix. The study of the influence metal cations on the thermal properties and the color of AN/ Itaconic acid copolymers are the objects of the present work.

\section{EXPERIMENTAL}

\section{Material}

Acrylonitrile (AN) (Sigma-Aldrich) was purified by distillation. Itaconic acid (IA) (Acros). $\mathrm{Ni}\left(\mathrm{NO}_{3}\right)_{2}, \mathrm{Cu}\left(\mathrm{NO}_{3}\right)_{2}$ and $\mathrm{Co}\left(\mathrm{NO}_{3}\right)_{2}$ were purchased from (Fluka), Sodium bisulfite and Potassium persulfate were obtained from (Panreac).

\section{Complexation of IA}

Copper(II), Cobalt(II) and nickel(II) complexes of the itaconic acid [IA/M( $\left.\left(\mathrm{NO}_{3}\right)_{2}\right]$ were prepared according to the following procedure:

Aqueous solution of itaconic acid (IA) (1 M) was refluxed with $(0.01 \mathrm{M})$ of metal salt solution for one hour at room temperature. The solid (colored) product was formed then it was filtered and dried for $24 \mathrm{~h}$ under vacuum oven.

The results of the complexes were identified by the UV/Vis and FTIR spectrophotometers.

\section{Copolymerization of IA with AN}

The copolymerization $\left[\mathrm{AN}-\mathrm{co}-\mathrm{IA} / \mathrm{M}\left(\mathrm{NO}_{3}\right)_{2}\right]$ was prepared via radical polymerization using sodium bisulfite $(5 \times 10-2 \mathrm{M})$ and potassium persulfate $\left(5 \times 10^{-2}\right.$ $M)$ as a redox initiator. Free-radical copolymerization of AN with $\mathrm{IA} / \mathrm{M}\left(\mathrm{NO}_{3}\right)_{2}$ at constant total monomer concentration $(0.1 \mathrm{M})$ in distilled water was carried out in glass bottles with polyethylene stoppers at $40^{\circ} \mathrm{C}$, using $0.01 \mathrm{~mol} \%$ initiator with respect to monomer feed. The solution was purged with nitrogen all over the reaction. The copolymerization reaction was allowed to take place for some intervals of time. Polymerization was terminated by precipitating the reaction mixtures in a large amount of cold methanol. The precipitated copolymers were purified by distilled water using soxhlet system and dried in vacuum oven, at $40^{\circ} \mathrm{C}$ to constant weight (Table1). The results of the complexes were identified by the UV/Vis and FTIR spectrophotometers.

\section{Characterization}

Infra-red spectroscopy spectra were measured on a Jasco 460 plus FTIR spectrophotometer by cast with potassium bromide $(\mathrm{KBr})$ disk and the range of data between $400-4000 \mathrm{~cm}^{-1}$. UV-visible spectrophotometric measurements were carried out by a shimadzu-1208 UV-Vis spectrophotometer. The samples were prepared by dissolving the copolymers in $\mathrm{N}, \mathrm{N}$-dimethylformamide at $25^{\circ} \mathrm{C}$.

The thermogravimetric analysis (TGA) was carried out on simultaneous thermal gravimetric analyzer (Perkin Elmer gravimetric analyzer TGA). The (TGA) performed from 25 to $500^{\circ} \mathrm{C}$ at heating rate of $10^{\circ} \mathrm{C} / \mathrm{min}$ in flowing dry nitrogen at a rate of $10^{\circ} \mathrm{C} / \mathrm{min}$. The morphology of poly acrylonitrile and modified poly acrylonitrile in presence of metal were examined by emission scanning electron microscopy (ESEM) using a (FEG-SEM/EDS) or LEO 440ZEISS/ LEICA model.

\section{RESULT AND DISCUSSION}

\section{UV-Vis spectra}

The $\mathrm{Co}, \mathrm{Ni}, \mathrm{Cu}$ complexes had been prepared according to above mentioned described method. The formation of the complex was confirmed by the appearance of the broad peak at $\lambda_{\text {max }}$ shown at UV spectrum and Table 1. The electron density of the-COO-group decreases as result of the complex formation with metal ions leading to $\lambda_{\text {max }}$ shift to shorter wavelength ${ }^{10,11}$. It is possible to establish the following order for the metal ion ability to stable complex with itaconic acid: $\mathrm{Co}(\mathrm{II}) \lambda_{\max }=690 \mathrm{~nm}$ ), $\mathrm{Cu}(\mathrm{II})\left(\lambda_{\max }=726 \mathrm{~nm}\right)$ and $\mathrm{Ni}(\mathrm{II})\left(\lambda_{\max }=750 \mathrm{~nm}\right)$ which is confirmed by order of chelating stability of metal ions 11 (Figure 1).

Moreover, the UV/Vis spectrum of each copolymer showed an extra broad peak when compared to the PAN spectrum (Figure 2). 


\section{FTIR spectroscopy}

Comparing the IR spectra of IA (c) and PAN

(a) and that of the copolymer of AN-CO- IA/Cu(NO $\left.\mathrm{NO}_{3}\right)_{2}$

(b) (Fig. 3). The latter showed the following:

1. Reduction of the broadness above $3000 \mathrm{~cm}^{-1}$ indicates the participation of the carboxylic groups in the coordination process with metal ions.

2. The (H-bonded) peak at $3448 \mathrm{~cm}^{-1}$ due to water molecules coordinated to the $\mathrm{Cu}$ (II) complex 10.

3. The $\mathrm{C}=\mathrm{O}$ carbonyl stretching of $\mathrm{AN}-\mathrm{co}-\mathrm{IA} /$ $\mathrm{Cu}\left(\mathrm{NO}_{3}\right)_{2}$ remains at the same wavenumber $\left(1700 \mathrm{~cm}^{-1}\right)$ as compared with IA monomer spectrum.

4. The nitrile group of $\mathrm{AN}-\mathrm{CO}-\mathrm{IA} / \mathrm{Cu}\left(\mathrm{NO}_{3}\right)_{2}$ copolymer shifted to higher wavenumber at $2362 \mathrm{~cm}^{-1}$ as compared to that of homopolymer AN which appear at $2245 \mathrm{~cm}^{-1}$, this shift might be attributed to the effect of electrostatic force between carbon atom of carbonyl group and $\mathrm{C}=\mathrm{O}$ in itaconic acid and nitrogen atom of nitrile groups as shown from Scheme 1 (Eq.1).

5. A shoulder like appearance at $2190 \mathrm{~cm}^{-1}$ near characteristic absorption for $\mathrm{C} \equiv \mathrm{N}$ at $2245 \mathrm{~cm}^{-1}$ may be attributed to the stretching vibration of $\mathrm{C}=\mathrm{NH}$ formed during copolymerization ${ }^{11}$.
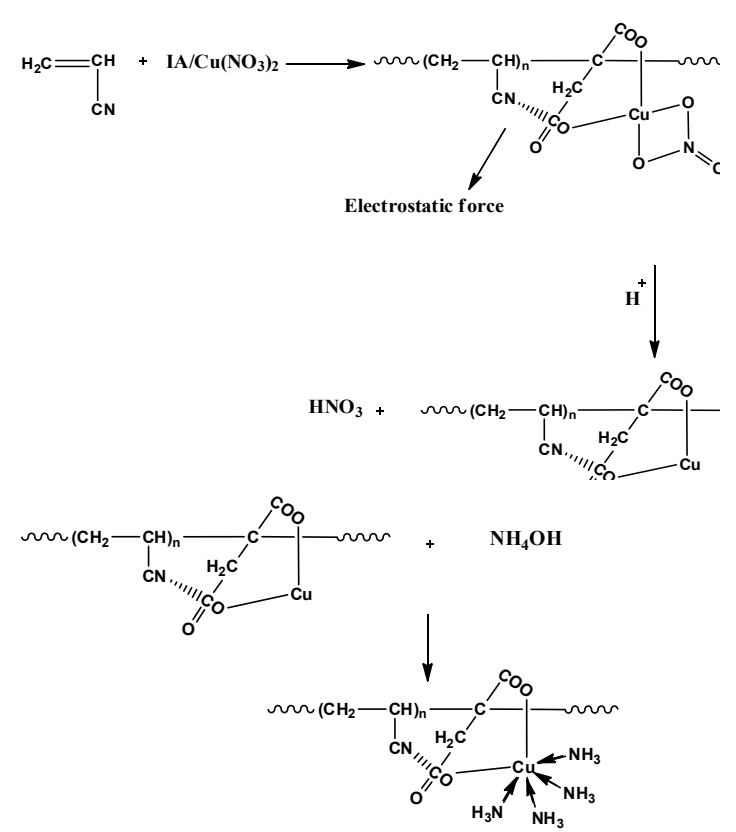

Eq3

Scheme 1. Incorporation of [ltaconic acid /Cu(II)] in presence and absence of ammonium hydroxide into poly acrylonitrile chains

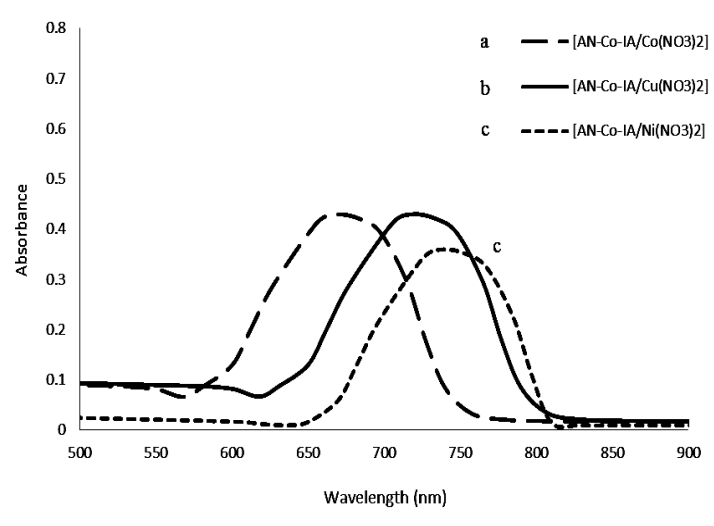

Fig.1. UV/Vis absorption spectra of (a) $\left[\mathrm{IA} / \mathrm{Cu}\left(\mathrm{NO}_{3}\right)_{2}\right]$, (b) $\left[\mathrm{IA} / \mathrm{Co}\left(\mathrm{NO}_{3}\right)_{2}\right]$ and (c) $\left[\mathrm{IA} / \mathrm{Ni}\left(\mathrm{NO}_{3}\right)_{2}\right]$

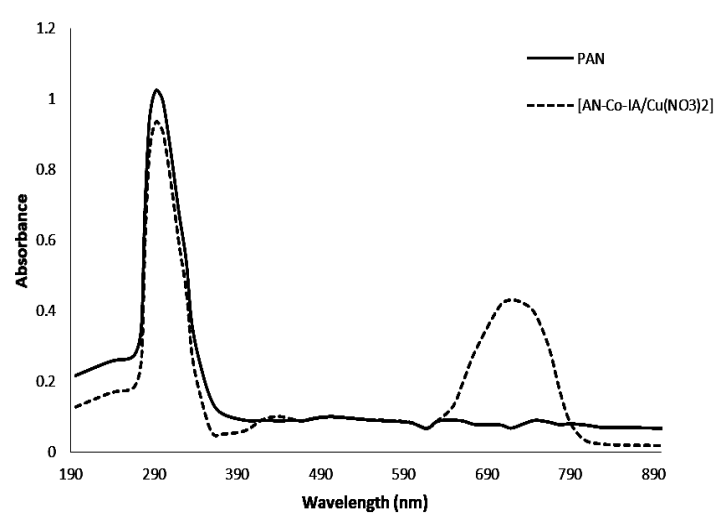

Fig.2. UV/Vis spectrum of (a) PAN as compared to that of (b) $\left[\mathrm{AN}-\mathrm{CO}-\mathrm{IA} / \mathrm{Cu}\left(\mathrm{NO}_{3}\right)_{2}\right]$

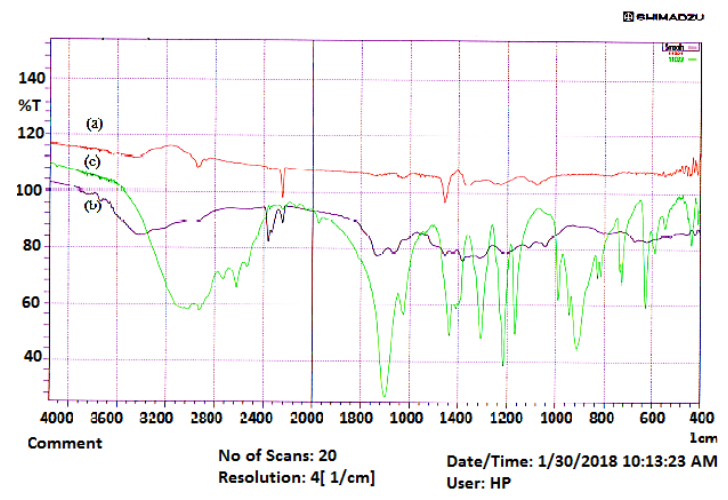

Fig. 3. FTIR Spectrum of (a) PAN (b) $\left[\mathrm{AN}-\mathrm{CO}-\mathrm{IA} / \mathrm{Ni}\left(\mathrm{NO}_{3}\right)_{2}\right]$ (c) Itaconic acid

\section{Determination of the copolymer compositions}

Determination of the composition of the $\left[\mathrm{AN}-\mathrm{co}-\mathrm{IA} / \mathrm{M}\left(\mathrm{NO}_{3}\right)_{2}\right]$ copolymers had been calculated from their IR spectrum. Various known compositions of PAN and IA were determined. The IR spectra of 
these mixtures were recorded to make a calibration curve (Fig. 4). The ratio of the intensity of the $\mathrm{C}=\mathrm{O}$ stretching band at $1720-1730 \mathrm{~cm}^{-1}$ to that of $\mathrm{C} \equiv \mathrm{N}$ stretching band at $2246 \mathrm{~cm}^{-1}$, [ICO/ICN] was plotted against the content of itaconic acid in the mixture. A linear relationship was obtained which can be expressed in the mathematical form as below by using the straight-line equation,

$$
\mathrm{Y}=\mathrm{MX}+\mathrm{C} \quad \mathrm{Y}=0.27 \mathrm{X}+0.24
$$

Where $Y=$ ratio of intensity of the carbonyl stretching band to the nitrile stretching band and $X$ = the contents (in mol \%) of itaconic acid. Table 2 showed the composition for various copolymers as shown from their IR spectra. All copolymers were found to be colored.

Table 1: Various [AN-co-IA/M( $\left.\left(\mathrm{NO}_{3}\right)_{2}\right]$ copolymer, $\lambda_{\max }(\mathrm{nm})$ values corresponding to the $\left[\mathrm{IA} / \mathrm{M}\left(\mathrm{NO}_{3}\right)_{2}\right]$ complex and their colors

\begin{tabular}{lccc}
\hline Copolymer & Color of the copolymer & $\lambda_{\max }$ & Image \\
\hline$\left[\mathrm{AN}-\mathrm{co}-\mathrm{IA} / \mathrm{Co}\left(\mathrm{NO}_{3}\right)_{2}\right]$ & Light pink & 690 & \\
{$\left[\mathrm{AN}-\mathrm{CO}-\mathrm{IA} / \mathrm{Cu}\left(\mathrm{NO}_{3}\right)_{2}\right]$} & Light blue & 726 & \\
& & & \\
{$\left[\mathrm{AN}-\mathrm{CO}-\mathrm{IA} / \mathrm{Ni}\left(\mathrm{NO}_{3}\right)\right]$} & Light green & 750 & \\
\end{tabular}

Table 2: The mole \% of IA for various copolymers*. [ ${ }^{*}$ data are obtained from IR spectra]

\begin{tabular}{|c|c|}
\hline Copolymer & $\mathrm{IA}(\mathrm{mol} \%)$ \\
\hline $\mathrm{AN}-\mathrm{CO}-\mathrm{IA} / \mathrm{Cu}\left(\mathrm{NO}_{3}\right)_{2}$ & 7.7 \\
\hline $\mathrm{AN}-\mathrm{Co}-\mathrm{IA} / \mathrm{Co}\left(\mathrm{NO}_{3}\right)_{2}$ & 5.3 \\
\hline $\mathrm{AN}-\mathrm{CO}-\mathrm{IA} / \mathrm{Ni}\left(\mathrm{NO}_{3}\right)_{2}$ & 7.2 \\
\hline
\end{tabular}

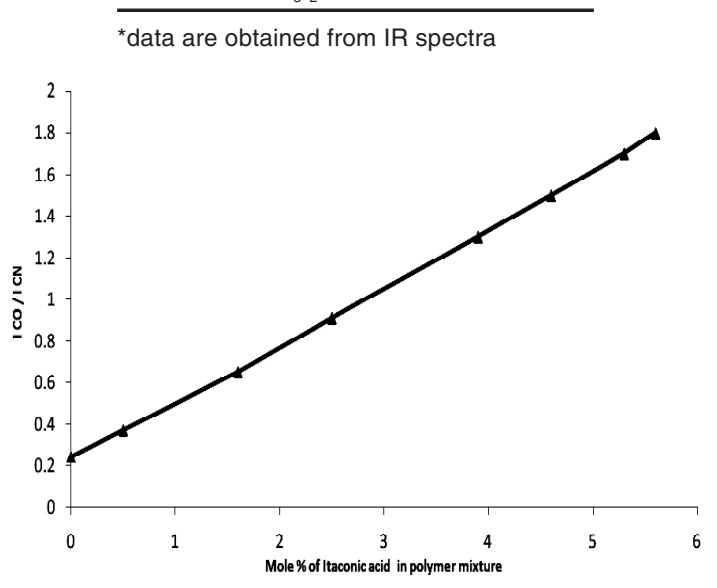

Fig. 4. Contents of Itaconic acid as a function of ratio of the intensities of carbonyl to nitrile, IR stretching bands

Thermal behavior of synthesized copolymers

The thermal stability of the copolymers was investigated by thermogravimetry (TGA), in a nitrogen stream, at a heating rate of $10^{\circ} \mathrm{C} \mathrm{min}{ }^{-1}$ and the rate of nitrogen flow was $20 \mathrm{ml} \mathrm{min}^{-1}$. A summary for the total mass loss percentage of AN-Co-IA/M $\left(\mathrm{NO}_{3}\right)_{2}$ copolymers in the presence of various concentrations of $\mathrm{NH}_{4} \mathrm{OH}$ solution are shown in Table 3.

\begin{tabular}{lc}
$\begin{array}{c}\text { Table 3: Weight loss } \% \text { as a function of } \\
\left.\text { temperatures of [AN-co-IA/M }\left(\mathrm{NO}_{3}\right)_{2}\right]\end{array}$ \\
\hline Polymers & Total Wt loss \% at \\
& $500^{\circ} \mathrm{C}$ \\
\hline PAN & 27.87 \\
AN-co-IA/Co $\left(\mathrm{NO}_{3}\right)_{2}$ & 24.31 \\
AN-co-IA/Cu$\left(\mathrm{NO}_{3}\right)_{2}$ & 24.87 \\
AN-co-IA/Ni $\left(\mathrm{NO}_{3}\right)_{2}$ & 30.42 \\
\hline
\end{tabular}

Figure 5 showed the initial decomposition temperature of $\mathrm{PAN}$ at $\mathrm{To}=307^{\circ} \mathrm{C}$ and the main mass loss reached to $27 \%$ at $500^{\circ} \mathrm{C}$. The results revealed that $\left[\mathrm{AN}-\mathrm{co}-\mathrm{IA} / \mathrm{Co}\left(\mathrm{NO}_{3}\right)_{2}\right]$ exhibited higher initial decomposition temperature $\left(\mathrm{To}=340^{\circ} \mathrm{C}\right)$ than the PAN homopolymer, while $\left[\mathrm{AN}-\mathrm{CO}-\mathrm{IA} / \mathrm{Ni}\left(\mathrm{NO}_{3}\right)_{2}\right]$ copolymer showed To at $270^{\circ} \mathrm{C}$, lower than PAN.

Moreover, the presence of $\mathrm{Cu}$ and $\mathrm{Co}$ in the copolymers reduce the mass loss percentage, at high temperatures to $24.87 \%$ and $24.31 \%$, respectively, as compared to PAN (27\%) (Figure 5).

The aforementioned data confirmed the extra thermal stability acquired by the AN-Co-IA due to the presence of metal cations. 


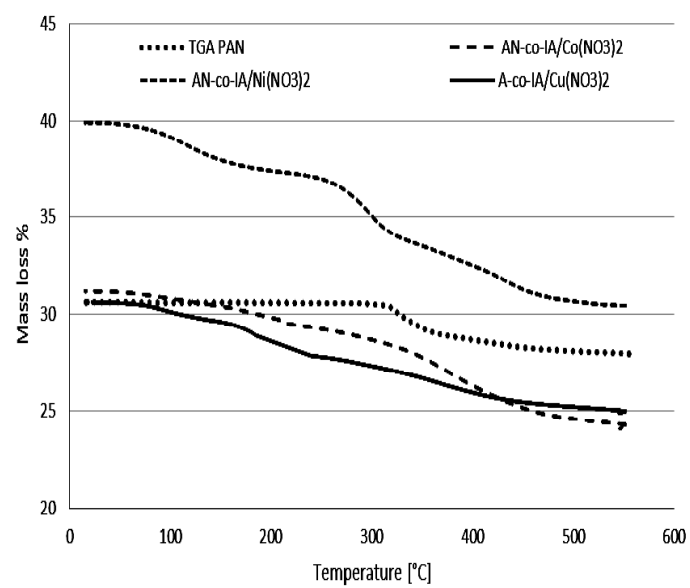

Fig. 5. TGA curves for a- PAN, b-[AN-CO-IA/Cu( $\left.\left(\mathrm{NO}_{3}\right)_{2}\right]$, c-[ANCo-IA/Co $\left.\left(\mathrm{NO}_{3}\right)_{2}\right]$ and d-[AN-co-IA/Ni(NO3)2] under nitrogen

Effect of addition various concentration of $\mathrm{NH}_{4} \mathrm{OH}$ on the self-coloration of $\left[\mathrm{AN}-\mathrm{CO}-\mathrm{IA} / \mathrm{Cu}\left(\mathrm{NO}_{3}\right)_{2}\right]$ copolymer

\section{Thermal degradation studies}

The $\mathrm{Cu}(\mathrm{II})$ ion is known to form $\mathrm{Cu}$ tetramine complex with ammonium hydroxide solution 12 leading to a deep blue color. Addition of the ammonia solution to the copper copolymer $\left[\mathrm{AN}-\mathrm{co}-\mathrm{IA} / \mathrm{Cu}\left(\mathrm{NO}_{3}\right)_{2}\right]$ cause deepening in its blue color. The reaction demonstrating the formation of $\left[\mathrm{AN}-\mathrm{Co}-\mathrm{IA} / \mathrm{Cu}\left(\mathrm{NO}_{3}\right)_{2}\right]$ in the presence of ammonium hydroxide is shown in Scheme 1 (Eq.3)

\section{IR Studies}

Increasing $\mathrm{NH}_{4} \mathrm{OH}$ concentration from 0.2 $\mathrm{N}$ to $0.8 \mathrm{~N}$ led to the deepness in the blue color of the resulting copolymer. This could be attributed to the formation of copper tetramine complex through the copolymer chains. To confirm this, the FTIR spectrometry was used.

Figure 6 showed the FTIR spectra of [ANco-IA/Cu( $\left.\left(\mathrm{NO}_{3}\right)_{2}\right]$ in presence of various concentration of $\mathrm{NH} 4 \mathrm{OH}$ solution. The results revealed that:

1. The nitrile group of copolymers appeared at the same wavenumber in $2360 \mathrm{~cm}^{-1}$.

2. An increase in the intensity of the shoulder like, which appear at $2245 \mathrm{~cm}^{-1}$. This could be attributed to the ability of $\mathrm{Cu}$ (II) to replace the acidic hydrogen in the imine group of itaconic acid moieties.

3. Increase of the peak broadness at 3400 $\mathrm{cm}^{-1}$ with the increase in the concentration of $\mathrm{NH}_{4} \mathrm{OH}$. This corresponds to the hydroxyl group of water molecules formed as a byproduct of the coordination process as shown in Figure 6 ( $a$ and $b$ ).

4. Stretching split bands of primary amine appeared between $3300-3400 \mathrm{~cm}^{-1}$ (it is small for aliphatic) $)^{13}$, while broad bending band of primary amine appeared at $1560 \mathrm{~cm}^{-1}$.

5. Two strong bands near 1400 and $1700 \mathrm{~cm}^{-1}$ may assign to the symmetric and asymmetric carboxylate ion ${ }^{14}$. Also, overtone of these peaks was observed at $3700 \mathrm{~cm}^{-1}$ and $2900 \mathrm{~cm}^{-1}$.

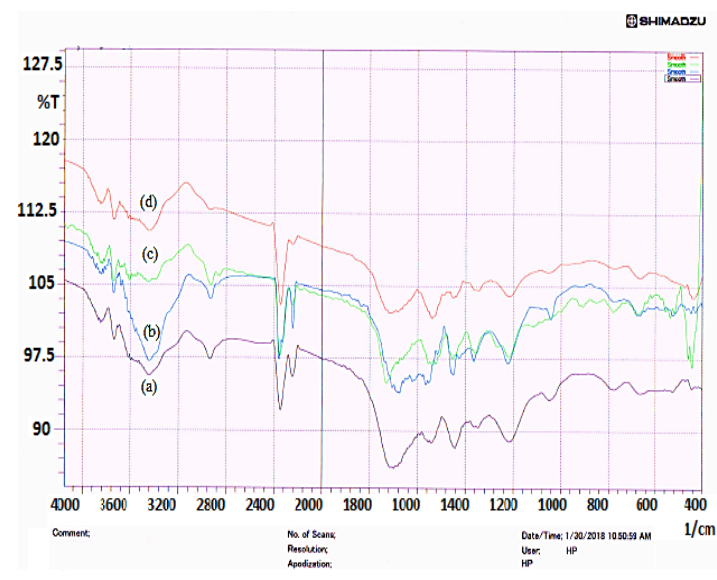

Fig. 6.FTIR Spectrum of $\left[\mathrm{AN}-\mathrm{CO}-\mathrm{IA} / \mathrm{Cu}\left(\mathrm{NO}_{3}\right)_{2}\right]$ in presence of (a) $0.8 \mathrm{~N}$ (b) $0.6 \mathrm{~N}$ (c) $0.4 \mathrm{~N}$ and (d) $0.2 \mathrm{~N}$

All the above-mentioned data confirmed the suggested structure of $\left[\mathrm{AN}-\mathrm{CO}-\mathrm{IA} / \mathrm{M}\left(\mathrm{NO}_{3}\right)_{2}\right]$.

\section{Thermal degradation studies}

Table 4 showed the percentage of total mass loss of the copolymer [AN-co-IA/Cu $\left.\left(\mathrm{NO}_{3}\right)_{2}\right]$. The percentage of weight loss of the copolymers was slightly affected by the addition of $0.2 \mathrm{~N}, 0.4 \mathrm{~N}$, $0.6 \mathrm{~N}$ and $0.8 \mathrm{~N} \mathrm{NH} 4 \mathrm{OH}$ solutions as shown from Table 4. The increase in the $\mathrm{NH}_{4} \mathrm{OH}$ concentration only affected the degree of the blue color of the copolymer rather than thermal stability.

\section{UV/Vis studies}

UV/visible spectra of the [AN-Co-IA/ $\left.\mathrm{Cu}\left(\mathrm{NO}_{3}\right)_{2}\right]$ in presence of various concentrations of ammonium solution (Fig. 7) showed that the copolymers formed in presence of various concentration of $\mathrm{NH}_{4} \mathrm{OH}$ were shifted to longer wavelength (Bathochromic shift) and possess the higher $\lambda_{\max }$ value (Hyperchromic effect) than $\left[\mathrm{AN}-\mathrm{CO}-\mathrm{IA} / \mathrm{Cu}\left(\mathrm{NO}_{3}\right)_{2}\right]$, which indicates the complexation formation. 


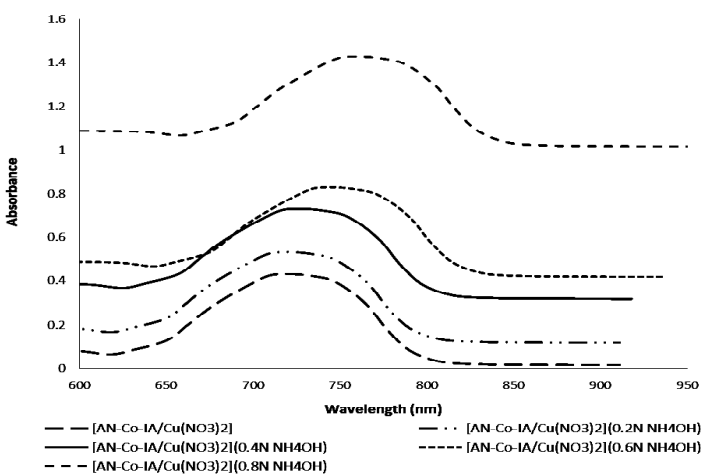

Fig. 7.UV/Vis absorption spectra of a- $\left[\mathrm{AN}-\mathrm{Co}-\mathrm{IA} / \mathrm{Cu}\left(\mathrm{NO}_{3}\right)_{2}\right]$ in presence of various concentrations (b) $0.2 \mathrm{~N}$, (c) $0.4 \mathrm{~N}$, (d) $0.6 \mathrm{~N}$ and (e) $0.8 \mathrm{~N}$ of $\mathrm{NH} 4 \mathrm{OH}$ solution

Fig. 4.Total Weight loss $\%$ as a function of temperatures of $\left[\mathrm{AN}-\mathrm{CO}-\mathrm{IA} / \mathrm{Cu}\left(\mathrm{NO}_{3}\right)_{2}\right]$ in presence of various concentrations of $\mathrm{NH}_{4} \mathrm{OH}$ solution

Concentration of $\mathrm{NH}_{4} \mathrm{OH}$ Color Total weight loss at $500^{\circ} \mathrm{C}$ $11 \mathrm{gm}$ of copolymer

\begin{tabular}{lcc}
\hline $0.0 \mathrm{~N}$ & Light blue & 24.8 \\
$0.2 \mathrm{~N}$ & Blue & 31.9 \\
$0.4 \mathrm{~N}$ & Blue & 31.7 \\
$0.6 \mathrm{~N}$ & Dark blue & 29.9 \\
$0.8 \mathrm{~N}$ & Very dark blue & 30 \\
\hline
\end{tabular}

From the aforementioned data, a thermal stable dark blue colored $\left[\mathrm{AN}-\mathrm{co}-\mathrm{IA} / \mathrm{Cu}\left(\mathrm{NO}_{3}\right)_{2}\right]$ copolymer could be obtained by an adding $0.6-0.8 \mathrm{~N}$ of ammonium solution (10 ml) per one gram of the copolymer.

\section{Morphological characterization}

The polymeric matrix of the (AN-co-IA/M)

\section{CONCLUSION}

The copolymerization of AN with IA metal complexes leads to the formation of colored copolymers. There will be no need for the dyeing process and the problem related to the fasting of the dye will vanish. The thermal stability and the color of the copolymers varied according to the type of metal. The $\left[\mathrm{AN}-\mathrm{CO}-\mathrm{IA} / \mathrm{Co}\left(\mathrm{NO}_{3}\right)_{2}\right]$ copolymer possessed higher thermal stability as compared to that of PAN. While, the pink colored. Ni copolymer copolymer was unique for the cation forming the copolymer complex. Thus, the morphology of the $\left[\mathrm{AN}-\mathrm{CO}-\mathrm{IA} / \mathrm{Cu}\left(\mathrm{NO}_{3}\right)_{2}\right]$ (Fig. 8b), appears different from that of $\left[\mathrm{AN}-\mathrm{CO}-\mathrm{IA} / \mathrm{Ni}\left(\mathrm{NO}_{3}\right)_{2}\right]$ (Figure $\left.8 \mathrm{a}\right)$.

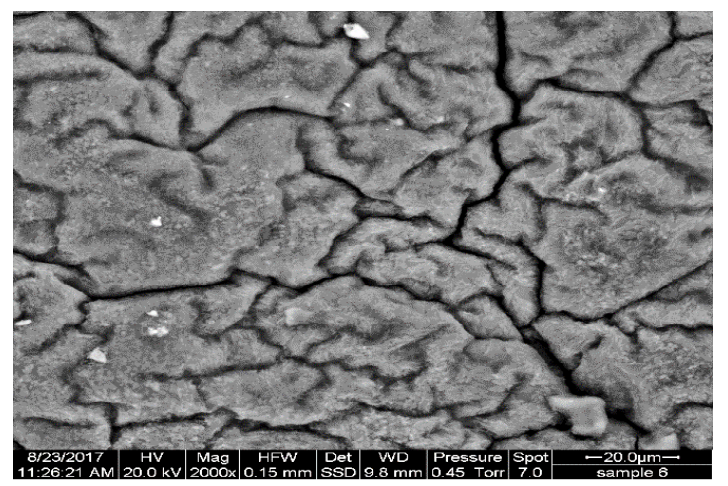

(a)

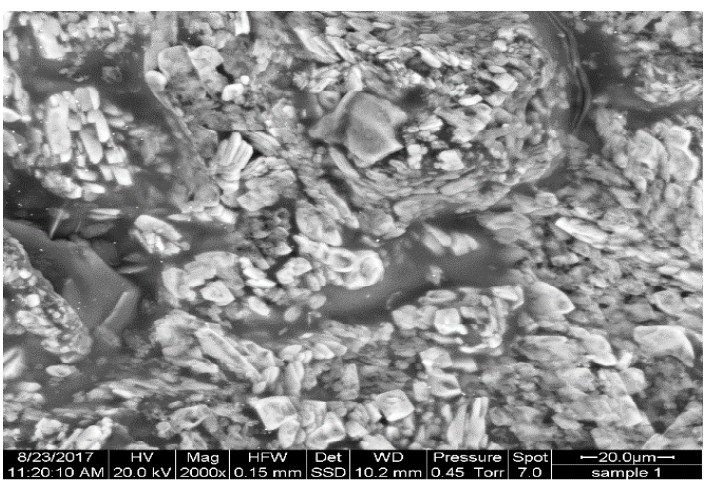

(b)

Fig. 8. ESEM of a-[AN-co-IA/Ni( $\left.\left(\mathrm{NO}_{3}\right)_{2}\right]$ and b-[AN-CO-IA/Cu( $\left.\left(\mathrm{NO}_{3}\right)_{2}\right]$

possessed less thermal stability than PAN as shown from their thermal gravimetric analyses. The addition of ammonia solution to the [AN-Co-IA/Cu(NO$\left.)_{3}\right)_{2}$ ] cause deepness in the blue color of the copolymer. $\mathrm{IR}$, UV/Vis spectra had confirmed the structure for the copolymers in presence of metals.

\section{ACKNOWLEDGMENT}

This research did not receive any specific grant from funding agencies in the public, commercial, or not-for-profit sectors.

\section{REFERENCES}

1. Bajaj, P.; Sreekumar, T. and Sen, K. Polym., 2001, 42, 1707-1718.

2. Abdel-Naby, A. Ultrason. Sonochem., 2012, 19(6), 1180-1185.
3. Atla, S., Raihane, M.; Hult, A.; Malkoch, M.; Lahcini, M. and Ameduri, B. J. Polym. Sci. Part A., 2013, 51(18), 38563866. 
4. Iqbal, M. S.; Jamil, Y.; Kausar, T. and Akhtar, M. J. Therm. Anal. Calorim., 2009, 96(1), 225-233.

5. An, Q.; Qiana, J.; Zhaoa, Q. and Gaob, C. J. Membrane. Sci., 2008, 313, 60-67.

6. Zhao, Q., Qian, J., An, Q., Zhu, Z., Zhang, P. and Bai, Y. J. Membrane. Sci., 2008, 311, 284-293.

7. Devasia, R.; Nair; C. P. and Ninan, K. N. Eur. Polym. J., 2008, 39(3), 537-544.

8. Devasia, R.; Nair, C. P. and Ninan, K. N. Eur. Polym. J., 2002, 38(10), 2003-2010.

9. Zhao, Y.; Wang, C., Yu, M.; Cui, C.; Wang, Q. and Zhu, B. J. Polym. Res., 2009, 16, 437-442.

10. Coskun, R.; Soykan, C. and Delibas, A. Eur.
Polym. J., 2006, 43(3), 625-637.

11. Bajaj, P.; Paliwal, D. and Gupta, A. J. Appl. Polym. Sci., 1993, 49(5), 823-833.

12. Lomozik, L.; Gasowska, A.; Basinski, K.; Bregier-Jarzebowska, R. and Jastrzab, R. J. Coord. Chem., 2013, 66(2), 261-273.

13. Pavia, D.; Lampman, G. and Kriz, G. Introduction to spectroscopy 3rd edition, Bellingham Washington, Western Washington University. USA: Brook/Cole Thomson Learning publisher.

14. Lakshmanan, B. Journal of the Indian. Institute of Science., 1956, 38(4) 217-219. 